\title{
An Examination of Judicial Independence in China
}

\begin{tabular}{|r|l|}
\hline Journal: & Journal of Financial Crime \\
\hline Manuscript ID & JFC-12-2015-0068 \\
\hline Manuscript Type: & Scholarly Article \\
\hline Keywords: & $\begin{array}{l}\text { Judicial Independence, Judiciary, Rule of Law, China, Fourth Plenary } \\
\text { Session }\end{array}$ \\
\hline \multicolumn{2}{|l}{} \\
\hline
\end{tabular}

SCHOLARONE $^{m}$

Manuscripts 


\title{
An Examination of Judicial Independence in China
}

\begin{abstract}
Purpose - The purpose of this paper is consider and evaluate judicial independence in China, through reviewing the value in its presence, assessing its current state in China, and evaluating what the future holds for it.

Design/methodology/approach - The paper reviews the benefits of judicial independence in its support of the rule of law. Following this, an evaluation of the current independence of the judiciary in China is presented. The reforms of the judiciary in the Fourth Plenary Session and the outlook for judicial independence in China is assessed.

Findings - The paper finds that judicial independence in China cannot be said to exist, being vulnerable to influence from a variety of sources. There is, however, progress observed and this is expected to continue.

Originality/value - This paper's consideration of judicial independence in China and its outlook is framed with discussions of the relationships between judicial independence and the rule of law, and the Chinese state and the rule of law. The paper should thus contribute to discussion of the development trajectory of China in this important facet.
\end{abstract}

Keywords Judicial Independence, Judiciary, Rule of Law, China, Fourth Plenary Session

Paper type Viewpoint

China has witnessed "the most concerted effort in world history to construct a legal system" (Alford, 2000). In its latest plenum, the Communist Party of China made a historic move to continue this progress, sparking a storm of domestic and international commentary. The session was pioneering on two counts: this was the first central committee plenary session to address the topic of rule of law and the first 
time substantial reforms were proposed to increase the independence of the judiciary (Pereenboom, 2014).

This essay begins by reviewing why such reforms are desirable. The importance of the judiciary is as their role as custodians of the law, and thus their importance is united with that of the rule of law. Indeed, judicial independence is regarded as a necessary condition for the existence of the rule of law. Thus this examination of the judiciary begins with reviewing the importance of the rule of law in development. Correspondingly, how judicial independence enhances the benefits of the rule of law is then considered.

The given analysis of judicial independence in China is dynamic. After contextualising the origins of the judiciary of China, the extent of its independence is studied. Following this, the essay seeks to understand where judicial independence is headed in the coming period: initially examining the motivation for reform, and subsequently evaluating the impact of the recent reforms for judicial independence.

\section{The Rule of Law in Development}

Understanding why the development community at large advocates so strongly the rule of law so strongly goes far to explaining its recent emphasis in Chinese policy.

\section{The Rule of Law and Development}

The rule of law is universally viewed as fundamental to the development of nations, both instrumentally and constitutively; Tamanaha (2004) observed: "No other single political ideal has ever achieved global endorsement". Its appeal is especially surprising given its political nature, anchoring the relationship between state and society around social and economic rules.

The importance of the rule of law is especially championed for its role in international development. The opening lines of the Universal Declaration of Human Rights (1948) illustrate its importance to societal development: "Whereas it is essential, if man is not to be compelled to have recourse, as a last resort, to rebellion against tyranny and oppression, that human rights should be protected by the rule of law". Its importance to development is further evidenced in it being targeted by development agencies, 
such as the Sustainable Development Goals asserting the aim to "promote the rule of law at the national and international levels"; and the World Bank, the General Assembly of the UN and other donors spending vast amounts promoting it (Ginsburg \& Melton, 2014).

\section{Defining the Rule of Law}

Whilst its popularity is evident, there can be "uncertainty about what the essence of the rule of law actually is" (Carothers, 2003). Meaningful discussion naturally necessitates a clear starting definition. Simply put, the rule of law is where all agents, public or private, are governed by and entitled to the benefits of the laws, which are followed and equally applied (Bingham, 2010).

The rule of law can be conceived narrowly or broadly: formal or 'thin' definitions, contrasting with a substantive or 'thick' definitions (Trebilcock \& Daniels, 2008). 'Thin' definitions make no judgement over the justness of laws, but define procedural attributes required by a legal framework. 'Thick' rule of law extends this to include political morality, where laws must promote substantive rights.

Tamanaha (2007) recognises two tasks of a thin rule of law. Firstly, it restrains government by requiring its compliance with laws and limiting its law-making power. Secondly, it maintains order, coordinates behaviour and enables transactions. Additionally, thick rule of law should also embody and enable justice. These functions offer many advantages, explaining the prominent role of the rule of law in development.

\section{Advantages of the Rule of Law}

The possible benefits of the functions of rule of law are many and varied, which may be categorised, although overlapping, as those of: predictability, economic growth, peaceful social order and justice.

A strong rule of law enhances predictability. It does so 'vertically' between citizens and government; and 'horizontally' among citizens (Tamanaha, 2007). This avoids arbitrary legal decision-making, and is recognised as a central requirement for rule of law. This regularity is an important facet of liberty: government is by consistent laws rather than discretion.

This improved predictability indirectly influences the long-established financial gain from rule of law: enabling and enhancing economic growth (Hayek, 1944). Fundamentally, rule of law provides the legal 
framework enabling much economic activity, such as incorporation, property rights, and money. This protection of property and persons encourages economic growth: reducing expropriation by other citizens or government both increases incentives to invest whilst and decrease expenditure on protecting assets. Greater consistency allows agents to anticipate costs and benefits of a contract so make more efficient decisions. It reduces transaction costs of entering and enforcing contracts, with deterrent mechanisms including litigation and criminal proceedings. The rule of law supports the sustainability of this growth by protecting the environment through environmental rights and the defining and prevention of natural resource exploitation.

The rule of law is vital to peaceful social order, deterring government and citizen misconducts. Restraining abusive or arbitrary exercise of government power is necessary for liberty, alongside preventing its indirect consequences of actions such as corruption. This is achieved by establishing laws government must conform to, and institutions to enforce this, such as judiciaries and regulatory agencies. Citizen misdemeanours are similarly managed: reducing crime, conflict and violence, which otherwise impede economic development and manifestly affect wellbeing.

Finally, the rule of law is fundamental to a moral society, entailing elements of justice. The commitment to a thin rule of law is itself a constituent of development (Sen, 2000). A thick rule of law encompasses many further elements of development. Take, for example, accessibility of justice: there cannot be rule of law without inclusive exercise of rights, including: affordable justice, effective and intelligible legal process and accessible courts - all constitutive of development. Another central principle of the rule of law, as well as development, is equality before the law, where citizens are subject to the same laws of justice regardless of race, gender, or other characteristics. Finally, the rule of law enshrines and protects human rights, explaining its espousal in the UDHR preamble.

\section{Rule of Law as an Ideal}

It is appropriate to regard the existence of the rule of law in its entirety as an ideal to be aspired towards. This is exemplified by Sir James Matthew's sardonic writing on of the accessibility to justice principle: "In England, justice is open to all, like the Ritz". Correspondingly, the advantages of rule of law enjoyed vary greatly, with its design and application having a substantial impact (Kennedy, 2013). In a 
development context, it should be noted that the quantity and quality of institutions required for rule of law are often exceedingly expensive. Whilst the rule of law may be an ideal, it remains "an ideal worth striving for, in the interests of good government and peace, at home and in the world at large" (Bingham, 2010). With their diversity and importance, it is clear why China so desires to the rewards offered by strong rule of law.

\section{Judicial Independence and the Rule of Law}

The attraction of strong rule of law is unmistakable, yet also evident is the potential for its value to vary with its implementation. This is especially the case with the institution that applies the laws: the judiciary. Judicial independence is fundamental to the rule of law since it strengthens its aforementioned advantages.

\section{A Necessary Condition}

Judicial independence is such that courts should not be subject to government or private influence; judges are independent of all authority, save that of the law. It is the cornerstone of the rule of law, as evinced in the following statement: "We are convinced that the independence of the judicial system, together with its impartiality and integrity, is an essential prerequisite for upholding the rule of law" [emphasis added] (United Nations General Assembly, 2012).

Such rhetoric is justified when it is demonstrable that judicial independence is a necessary condition for the presence of rule of law, as argued by Raz (1979). Starting by minimally defining the rule of law as "people should obey the law and be ruled by it", he infers an ultimate premise: it must be capable of guiding the behaviour of its subjects. This necessitates judicial independence, amongst other conditions. Without independence, courts no longer consistently apply the law, so people will act according to their guess as to what the courts will rule, such as how a government may influence the ruling. Therefore the law can no longer be said to rule.

\section{Reinforcing the Advantages of the Rule of Law}


The central aim of judicial independence is to empower judges to apply the law impartially and consistently, and so best confer the benefits of the rule of law.

Firstly, it enhances the predictability of the rule of law (North \& Weingast, 1989). The alternatives to judicial independence are far less so: it would be difficult to guess how judges may be influenced and indeed an arbitrary enforcement of the law is, by definition, wholly unpredictable.

Judicial independence significantly enhances the rule of law economic benefits, for two reasons: credibility and transaction costs (Feld \& Voight, 2003). Market economies require property rights, yet a promise to honour property rights is not credible: after the citizens invest, the state has an incentive to expropriate the valuable asset, such as the land grabs seen in China, breaking its 'promise' of property rights. Yet society is better off with credible property rights: citizens and governments achieve higher incomes and taxes respectively. Establishing an independent judiciary makes this commitment, and other government 'promises' codified by legislation, credible since independent judges will enforce them staunchly. Transaction costs are reduced not just this improved predictability, yet also the knowledge of fair adjudication leading to reduced enforcement costs of contracts.

Judicial independence is essential to maintaining a peaceful social order. The rule of law is strongest when it is collectively trusted that it will be enforced, which judicial independence assists. Judicial independence is powerful at reducing corruption, making it more difficult for special interests to influence the law, having to deal with multiple institutions of power (Davis \& Trebilcock, 2008).

Finally, an independent judiciary strengthens the elements of justice conferred by the rule of law. Benefits such as equality before the law, accessibility of justice or human rights all require unbiased adjudication.

\section{Insufficiency of Independence}

Granting the judiciary independence is insufficient to realising its potential advantages. Legal provision of independence does not assure independence will exist in reality; other characteristics are needed of the judiciary, and ever-increasing independence can prove counterproductive.

'De jure judicial independence', the formal rules granting judicial independence, should be distinguished from 'de facto judicial independence', whether it exists in practice (Feld \& Voigt, 2003). De 
facto judicial independence is far from secured by de jure measures alone, requiring further institutional protections to be meaningful. Ultimately, judicial independence requires additional institutions to come to defend against violations of judicial independence, such as a free press or democracy (Ginsburg \& Melton, 2014). Alternatively, judges may have personal biases: where the judiciary is drawn from a narrow subset of society, such as having similar pre-judicial experience and affiliations, this creates the opportunity for prejudice. This dependency on broader institutional context indicates independence should be recognised to be a continuous and multifaceted concept and should be conceived as "not a binary condition but exists on a continuum of relative independence and accountability" (Cross, 2003).

Christine Largarde stated: "Above all, [the rule of law] requires a competent and independent judiciary to implement the law consistently, predictably and transparently" (2013). Largarde reinforces the necessity of judicial independence, yet also appends further competences. Whilst judges may be impartial, the rule of law and its benefits require consistent application of the law. Independence is critical to this, but so must judges be sufficiently capable to interpret and apply the law accurately.

A factor in judicial competence is its accountability: maximum independence implies no direct responsibility. There is a tension between judicial independence and responsibility (Bobek, 2008), consequently it has been recommended that increasing judicial independence should be accompanied by measures to ensure judicial accountability (Asian Development Bank, 2003).

\section{Current Independence of Judiciary}

Judicial independence is a broad concept, thus is examined from a variety of perspectives. An understanding of the current state of the judiciary will depend in part on understanding its context and its cultural relevance. Consequently, a brief overview is first given of the legal and judicial systems of China.

\section{Legal System}

The immense effort by China to strengthen legal system is unprecedented, yet its argued that it lacks a culture of deference to the rule of law. This is seen in the origins of its legal system and its ambiguous constitution underpinning it. 
The Chinese legal system evolved from two competing traditions. Confucianism viewed norms of behaviour as essential to good government and preferable to positive laws. Legalism emphasised positive law as "an instrument of state power imposed on people for their own good" (Bary, 1998). Consequently, an early scepticism for the law and its uses existed (Orts, 2000).

The legal system is primarily based on the civil law model, specifically German-influenced, also drawing from Socialist law of Soviet Russia (Harvard Law School China Legal Research). In a Civil Law system, judges establish case facts and apply relevant law, thus impartial adjudication is crucial. China has used several constitutions during its recent history, with its current constitution being established amongst the sweeping reforms of Deng Xiaoping in 1982 (Cohen, 1978).

The Constitution of the People's Republic of China (henceforth the Constitution) advances principles such as all citizens being equal under the law (Art.33), gurantees human rights (Art.33) and, pertinently, the rule of law: "The People's Republic of China governs the country according to law and makes it a socialist country under rule of law"(Art.5). Ambiguously, whilst the Constitution defines itself as having "supreme legal authority" (Preamble), it enshrines the principle of the "leadership of the Communist Party" (Preamble). However, these conditions are mutually exclusive: there can only be one ultimate leader.

\section{Judicial System}

The current Chinese courts are split between the Local People's Courts (divided between Grassroots, Intermediate and Higher) and Special People's Courts (Military, Maritime, and Transportation), and ultimately overseen by the Supreme People's Court (PKU Law). Whilst this structure is comparable to Western ones, its evolution is less commendable in terms of the independence and competence of its judiciary.

China is "a country not known for judicial independence" (Hung, 2002). An independent judiciary conspicuously absent from traditional China: "China has no historical office that corresponds to the Western idea of a judge. China lacks any history of an independent judiciary. The magistrate ${ }^{1}$ was an extension of the Emperor - no limits could restrain him” (Berring, 2004).

\footnotetext{
${ }^{1}$ The magistrate performed a judicial function, amongst others (Watt, 1974)
} 
Even when established, recruitment to the judiciary was hardly conducive to creating a capable institution. The judiciary was only separated from administrative bodies at the turn of the $20^{\text {th }}$ century (Chen, 2013), and judges were appointed primarily for their political status rather than legal knowledge, often from the military or security forces (Cohen, 1997). This practice continued with the Communist Party of China (henceforth the Party), with judges customarily from the Party or the military, although legal training was later required in the 1980s (Lubman, 1999). Whilst better trained, these judges nevertheless began upon graduation without practical experience. Consequently, the senior judges of today are poorly trained.

\section{Provision of Judicial Independence}

The legal establishment of judicial independence is a necessary condition for its existence. The Constitution provides this: "the people's courts exercise judicial power independently in accordance with the provisions of the law, and are not subject to interference from any administrative organ, public organisation or individual" (Art.126). Additionally, the People's Republic of China Judges Law (henceforth Judges Law) orders "no interference from administrative organs, public organisations or individuals" (Art.8). Consequently, this necessary condition is met; a measure of de jure judicial independence is present.

Nonetheless, the finality of judicial independence is contradicted by the Constitution also declaring the "supreme legal authority of the Communist Party". Thus, akin to the purported legal authority of the Constitution, the established judicial independence is undermined by this constitutional contradiction. Further damaging is that rather than solely applying the law, judges are legislated to "safeguard State interests" (Art.7, Judges Law).

\section{Judges' Terms of Office}

The terms of judges' recruitment, employment and departure greatly reduces their independence, as examined from a variety of persectives. 
The Party impacts judicial decisions indirectly through employing favourable judges. The Party approves all judicial appointments and personal decisions (CECC ${ }^{2}$ ) and requires judges to have strong political acumen (Art.9, Judges Law).

In office, judges are susceptible to corruption. Judicial salaries are low for the level of training required, ranging between 50,000 to 70,000 yuan (approximately $£, 5,000-£, 7,000$ ) for young judges; there is common perception of judicial corruption (Peerenboom, 2004). Judicial competence may be further demeaned by low salaries and judges often being paid per case completed (Wang, 2013).

Judges do not enjoy either fixed or life tenure (McConville, 2011). Instead, they are appraised including the criterion "outstanding deeds in safeguarding the interests of the State", with the possibility of salary adjustment, dismissal, or punishment (Art.28, Judges Law).

\section{Institutional Context of Judiciary}

Even if judges were individually independent, de facto judicial independence requires adjudications to not be interfered with internally coupled with external support being be unbiased. Neither institutional condition is satisfied.

The procuratorate and the People's Congress have the power to supervise the judges and call for reconsideration of cases (CECC). Political-Legal Committees, which include high-ranking Party members within the court, are intended to supervise cases but this often equates to adjudication (Pereenboom, 2008). Alongside this supervisory role, the procuratorate is the prosecutor (CECC), which creates a substantial conflict of interests. Judges in lower courts frequently seek the opinions of higher courts before making decisions on cases (CECC), reducing their autonomy and undermining the appeals procedure.

The external relationship of the courts with the security services further reduces impartial application of the law. Problems include: heavy reliance on confessions (Financial Times, 2014); defendants effectively presumed guilty until proven innocent (Chen, 2007); police collecting most case evidence (McConville, 2011); and widespread use of torture (Amnesty International, 2014). Such practices

${ }^{2}$ U.S. Government Congressional-Executive Commission on China Annual Report 
present conflicts of interest and bias the judicial system in favour of the state (Human Rights Watch, 2008), evidenced in a 99.93\% conviction rate achieved (Japan Times, 2014).

\section{Extrajudicial Powers}

Yet the most egregious affront to judicial independence is where the criminal justice system is not even used for certain cases.

The Party directly adjudicates certain cases through the Central Commission for Discipline Inspection (CCDI), with powers to detain and interrogate those suspected of malfeasance in the party, which are largely corruption investigations of Party officials (NY Times, 2012), and requires no warrants and are not subject to any oversight. Although the worst punishment it can administer is dismissing officials, its investigations are frequently transferred to the judicial system where heavy sentences are imposed (Washington Post, 2014). The complete absence of even ostensible judicial independence leaves it vulnerable to political abuse, of which it has been criticised in the recent aggressive anti-corruption drives (Financial Times, 2014).

\section{Parchment Barriers}

Whilst independence was recognised to be a continuous and multifaceted concept, the independence of the judicial judiciary is compromised in almost all respects examined. It is vulnerable to influence from local government and rich private citizens, yet it is worst affected by the Party.

At best, where the Party has no interest in the case, judges are still influenced in their requirement to consider social stability in their ruling; at worst, the Party disregards the judicial system and adjudicates cases itself. Thus whilst judicial independence is somewhat legally provided, this amounts to 'parchment barriers', with no meaningful protection for judges in reality. Failing the necessary condition of judicial independence, the rule of law cannot be said to exist in China.

\section{Determinants of Future Judicial Independence}

How the future of the judiciary is envisioned depends on two key factors: firstly, examining how China culturally relates to judicial independence, as a fundamental constraint on judicial independence; 
and secondly, investigating the development trajectory of China as a crucial source of increasing judicial independence.

\section{Cultural Context of Judicial Independence}

The cultural context of the judiciary impedes trains any future increases in independence, due to how China perceives the law.

The Party summarises its position as following "socialist rule of law with Chinese Characteristics"; a phrase that has contrasting meanings to the West and China. By Western understanding of the rule of law, an authoritarian government and the rule of cannot coexist since both claim ultimate authority. Consequently, socialist rule of law is "like a rooster dreaming that he can lay eggs" (Biao, 2014) - a political oxymoron. This mutual exclusivity applies equally to judicial independence and authoritarian government. The crux of the matter is it amounts to the "permanent contradiction" of granting any such authority to institutions whilst maintaining the Party is still the ultimate leader capable of overriding any legislation (Human Rights Watch, 2008).

Although China's modern legal system was initially borrowed from the West, China understands and proceeds with the institution on its own terms. Always, China (or at least Party officials) takes the leadership of the Party, implicit or explicit, as final. This is justified by the Party representing the interests of the people, describing itself as a "democratic dictatorship" (Preamble, Constitution). Such language also reinforces how China perceives such concepts - be it rule of law or democracy - differently to the West. This is evidenced in the following statements. The previous President of the Supreme People's Court, Xiao Yang, stated, “The power of the courts to adjudicate independently doesn't mean at all independence from the Party. It is the opposite, the embodiment of a high degree of responsibility vis-àvis Party undertakings." (China Court Daily, 2008) and an editorial in the People's Daily, an official government newspaper, announced: "the rule of law should only be advanced by the rule of the Party and there are CPC fundamentals that should not be overridden" (People's Daily, 2014). During the Hong Kong democracy protests, the People's Daily called for protection of the rule of law despite the protests in general being legal; thus demonstrating the Party using 'rule of law' to mean control by the law (Gewirtz, 2014). 
Therefore Chinese leaders evidently have a different cultural conception of judicial independence and the rule of law, such that they are always subject to the Party and with this influence generally not being considered an improper restraint (CECC). Rather than use the Party phrase of 'socialist rule of law with Chinese characteristics' and its ambiguity, it would be more apt to describe China as having 'rule of the Party', using the law as its tool (Chen \& Zhong, 2005) ${ }^{3}$. This is a fundamentally constraint to increasing judicial independence, since in this setting the judiciary will forever be subject to Party control.

\section{The China Paradox}

The development path of China and how the rule of law relates to this has been termed 'The China Paradox', with the trajectory of the economy is the key driver of increased judicial independence.

This 'rule of the Party' runs against the grain mainstream economic theory. North (1990) stated that a credible, low-cost, formal regime of third-party contract enforcement was essential to sustained development. The so-called paradox arises since China has witnessed extraordinary economic growth, yet lacks this supposedly essential institution.

Trebilcock and Leng (2006) ascribe an implicit social contract to the Party and the population to resolve the paradox: the latter will accept authoritarianism if it delivers high economic growth. To achieve such prosperity, the Party must maintain a strong reputation for respecting contracts into which domestic and foreign investors enter, thus enforcing contact law without credible legal institutions. This informal contract enforcement is evidenced through 'guanxi', local networks where most business is done; thus "Businesspeople in China keep their promises (most of the time) not because they are required to by law, but because reneging on a 'contract' is likely to destroy the businessperson's ability to do business in the future” (McMillian \& Naugton, 1996).

China has long-recognised the importance of legal institutions to its economy. When China moved to a "socialist market economy" (increasing the free market in its mixed economy) in the 1992 14th National Party Congress announcement, it was followed by the slogan "a market economy is a rule of law economy" being adopted by China's leaders, who recognised the need for the advantages of the rule of law, especially the economic ones (Dingjian, 2010). China is now at a crossroads. The third plenum of the

\footnotetext{
${ }^{3}$ The alternative leading depiction is China has 'rule by law', see (Birney, 2013) for why 'rule of the Party' is superior
} 
18th Party Congress announced a bold plan for transitioning China from the state-investment led development model to a more consumption-based model in order to escape the middle-income trap, the transition from a lower to an upper middle-income country (OECD, 2013). Current informal legal institutions cannot satisfactorily support an increasingly sophisticated economy, such as needs for increased foreign investment, the development of multinational corporations, or a more effective public sector. Currently, corruption and crony capitalism are increasing concerns. This motivation for improved legal institutions is acknowledged in the latest plenum: "The comprehensive construction of a moderately prosperous society has entered a decisive state".

\section{Reform of the Judiciary}

Having understood the key sources of reform, a viewpoint is offered of the recently proposed policies and their implications for the future of judicial independence.

\section{Rule of Law in the Plenum}

The 'Fourth Plenary Session of the 18 $8^{\text {th }}$ CPC Party Central Committee' session, held 20-23

October, passed 'Decision Concerning Some Major Questions in Comprehensively Promoting Governing the Country According to Law', explained in a communiqué, focused on developing the rule of law. As Xi declared: "we will unflinchingly march the path of socialist rule of law with Chinese characteristics".

Emphasis was given to increasing a rule of law culture. It is difficult, if not impossible, to manage misbehaviour with supervision and ex-post punishment alone; a norm of respecting the law is needed among citizens and government. "We must make people understand that the law is a powerful tool to guarantee their own rights and is a behavioural standard that must be respected," states the communiqué. Correspondingly, the need for 'rule of virtue', something of a quasi-Confucian idea, was advanced to complement the rule of law. This cultural shift was largely sought through calling for increased respect for the Constitution.

Judicial Reforms in the Plenum 
Additionally, comprehensive reforms were announced for the legal system, the administrative system, military and - most significantly - the judiciary. Central to improving rule of law, policies to increase judicial independence were taken.

A number of improvements to the terms of office for the judiciary were proposed. First and foremost, measures were taken to reduce the influence of local government. This included: centralising control over court finances and judicial salaries; transferring control over appointment of senior judges to central government; establishing a system of national judicial circuits transcending regional boundaries. A number of policies improved transparency. Notably, the establishment for recording and investigating instances where Party or government officials interfered in judicial activities; and trials opened up with judgements made available online. Finally, many ordinary cases were to be tried without interference from court presidents or adjudicative committees, decreasing administrative influence.

These improvements internal to the judicial process were coupled with improved external supports, critically with police and security services. Improved evidentiary rules, strengthening laws around confessions obtained through torture, and ensuring defendants had the right to call witnesses were introduced. Ex-parte meetings between judges and parties or their lawyers were prohibited. Finally, legal aid was expanded, thus decreasing the influence of the wealth of parties on the adjudicative process.

An effective judiciary requires competent judges and judicial independence should be balanced with accountability, and reforms targeted these also. Prospective judges must now meet higher educational standards, pass unified national exams, and undergo training before assuming their post. The accountability of judges will be increased with them bearing lifetime responsibility for decisions; increased penalties for misconduct and wrongly decided cases; and individual cases continued to be supervised by the procuratorate to keep judges accountable.

\section{Concluding Remarks}

Through this examination of judicial independence in China, a tale of progress emerges: from non-existent judicial independence; through to its legal establishment but lacking strong surrounding 
institutions; and now with recent reforms seeking to strengthen the judiciary against some of the main sources of potential influence.

From every perspective analysed, considerable vulnerabilities were present in the judiciary. Yet there are reasons for cautious optimism. Firstly, the arguments for increased judicial independence are compelling: it reinforces the pervasive benefits of rule of law and is especially vital for China during this transitional phase; thus government focus on this issue is anticipated to only increase. Secondly, the recent reforms are expected to increase judicial independence, focusing on improving the terms of office and external institutional relationships.

Yet Party rhetoric around the plenum should not be taken at face value, recalling China has a history of an instrumentalist perception of the law and a different cultural understanding of the concept. The context to the reforms is $\mathrm{Xi}$ has overseen further constraints on political freedoms, such as freedom of assembly, and issued 'Document 9' (2013), an internal Party communiqué warning of dangers of promoting Western concepts, including the rule of law. Whilst judicial independence may increase, in terms of a thick conception of rule of law, the reforms represent more of a confirmation of the status quo substantial progress since the law is still being used instrumentally to control corruption and deliver growth. The authority of the Party shows no signs of receding, from its superiority over the Constitution to its extrajudicial handling of corruption. Yet whilst this will constitutively limit judicial independence, there is still scope for much advance even in the current framework, such as reducing influence from local government or private agents.

The reforms are consistent with an incremental approach favoured by China's leadership. Judicial independence should be viewed as having taken a step in the right direction, but there is certainly a long way left to go. 
Bibliography

Alford, W (2000) Exporting the 'Pursuit of Happiness'. Harvard Law Review Vol. 113

Amnesty International (2014) China's booming torture trade revealed. Available from: https://www.amnesty.org/en/articles/news/2014/09/china-s-booming-torture-trade-revealed/

Asian Development Bank (2003) Law and Policy Reform at the Asian Development Bank Current Independence of Judiciary. Available from: http://www.asianlii.org/asia/other/ADBLPRes/2004/3.pdf

Bary, T (1998) Asian Values and Human Rights. Cambridge: Harvard University Press

Berring, R (2004) Rule of Law: The Chinese Perceptive. Journal of Social Philosophy, Vol. 35

Bingham, T (2010). The Rule of Law. London: Penguin

Birney, M (2013) Decentralization and Veiled Corruption under China's Rule of Mandates. World Development Vol. 53

Bobek, M (2008) The Fortress of Judicial Independence and the Mental Transitions of the Central European Judiciaries. European Public Law, Vol. 14

Carothers, T (2003). Promoting the Rule of Law Abroad. Rule of Law Reform Series working paper Vol.1

Chen, J (2008) Cbinese Law: Context and Adventure. Boston: Brill Publishers

Chen \& Zhong (2005) Leadership in a Changing China. New York: Palgrave MacMillan

Communist Party of China (1995) Judges Law of the People's Republic of China. Available from:

http://en.chinacourt.org/public/detail.php?id=2692

Communist Party of China (2004) Constitution of the People's Republic of China. Available from:

http://www.npc.gov.cn/englishnpc/Constitution/node_2825.htm

Cohen, J (1978) China's Changing Constitution. The China Quarterly, Vol. 76

Cohen, J (1997) Reforming China's Civil Procedure: Judging the Courts. The American Journal of Comparative Law, Vol. 45

Congressional Executive Committee on China. Judicial Independence in the PRC. Available from:

http://www.cecc.gov/judicial-independence-in-the-prc

Cross, F (2003) Thoughts on Goldilocks and Judicial Independence. Ohio State Law Journal Vol. 195

Davis, K and Trebilcock, M (2008) The Relationship Between Law and Development: Optimists versus Skeptics. American Journal of Comparative Law, Vol. 56

Dingiian, C (2010) China's Journey Towards the Rule of Law: Legal Reform 1978-2008. Boston: Brill Publishers

Feld, L and Voigt, S (2003) Economic Growth and Judicial Independence: Cross Country Evidence Using a New Set of Indicators. CESifo Working Paper Series No. 906

Gewirtz, p (2014) What China Means by Rule of Law'. NY Times. Available from: http://www.law.yale.edu/documents/pdf/Intellectual_Life/What_China_Means_by_Rule_of_Law_NY Times.pdf 
Harvard Law School China Legal Research. Available from: http://guides.library.harvard.edu/chineselegalresearch

Hayek, F. (1944) The Road to Serfdom. Chicago: University of Chicago Press

Hornby, L (2014) China eyes rules-based system but flexes extrajudicial muscles. Financial Times. Available from: http://www.ft.com/cms/s/0/2cc4981c-5448-11e4-84c6-

00144feab7de.html?siteedition=uk\#axzz3TY8NH7ei

Human Rights Watch (2008) Walking on Thin Ice. Available from:

http://www.hrw.org/en/node/62248/section/6

Hung, V (2002) China's WTO Commitment on Independent Judicial Review: Impact on Legal and Political Reform. Available from: http://carnegieendowment.org/files/ajcl1.pdf

Jacobs, A (2012) Accused Chinese Party Members Face Harsh Discipline. New York Times. Available from: http://www.nytimes.com/2012/06/15/world/asia/accused-chinese-party-members-face-harshdiscipline.html?pagewanted $=$ all\&_r $=0$

Jiji, A (2014) China chalkes up staggering conviction rate. Japan Times. Available from:

http://www.japantimes.co.jp/news/2014/03/10/world/china-chalks-up-staggering-99-93-convictionrate/\#.VPNFwvmsWrE

Kennedy, (2013) Rule of Law and Economic Development after 2015: The Importance of Choices. Available from: http://www.bangkokdialogue.org/

Largarde, C (2013) Strong Laws and Institutions for a Strong Global Economy. Available from: https://www.imf.org/external/np/speeches/2013/060413b.htm

Lubman, S (2000) Bird in a Cage: Chinese Law Reform after Twenty Years. Northwestern Journal of International Law \& Business, Vol. 20

McConville, M (2011) Criminal Justice in Cbina: An Empirical Enquiry. Cheltenham: Edward Elgar Pub

McMillian \& Naugton (1996) Reforming Asian Socialism: The Growth of Market Institutions. Michigan: University of Michigan Press

Melton, J and Ginsburg, T (2014) Does De Jure Judicial Independence Really Matter? A Reevaluation of Explanations for Judicial Independence. Journal of Law and Courts Vol. 2

North, D. (1990) Institutions, Institutional Change and Economic Performance. Cambridge: Cambridge University Press.

North, D and Weingast, B (1989) Constitutions and Commitment: The Evolution of Institutional Governing Public Choice in Seventeenth-Century England. The Journal of Economic History Vol. 49

OECD (2013) The People's Republic of China: Avoiding the Middle-Income Trap. Available from: http://www.oecd.org/china/China-Brochure-eng-September2013.pdf

Orts, E (2000) The Rule of Law in China. Vanderbilt Journal of Transnational Law, Vol. 33

Rafferty, K (2014) China's rule by law, not of it (quotes Teng Biao). Japan Times. Available From: http://www.japantimes.co.jp/opinion/2014/11/02/commentary/world-commentary/chinas-rule-bylaw-not-of-it/\#.VPTL_vmsWrE

Pereenboom, R (2004) China's Long March toward Rule of Law. Cambridge: Cambridge University Press 
Peerenboom, R (2014) Fly High the Banner of Socialist Rule of Law with Chinese Characteristics! What Does the 4th Plenum Decision Mean for Legal Reforms in China? Available from: http://dx.doi.org/10.2139/ssrn.2519917

PKU Law (2015) The Legal System of China. Available from:

http://www.lawinfochina.com:83/legal/Display_1.asp

Raz, J (1979) The Authority of Law. Oxford: Oxford University Press

Sen, A. (2000). Development as freedom. New York, Anchor Books

Tamanaha, B (2004) One the Rule of Law: History, Politics, Theory. Cambridge: Cambridge University Press.

Tamanaha, B (2007) A Concise Guide to the Rule of Law. St. John's Legal Studies Research Paper Vol.7

Trebilcock \& Leng (2006) The Role of Formal Contract Law and Enforcement in Economic Development. Virginia Law Review, Vol. 92

UN General Assembly (1948) Universal Declaration of Human Rights. Available from:

http://www.refworld.org/docid/3ae6b3712c.html

United Nations General Assembly (2012) Declaration of the High-Level Meeting of the 67th Session of the General Assembly on the rule of law at the national and international levels. Available from: http:/ /www.ipu.org/splze/unbrief12/dr-declaration.pdf

Wan, W (2014) Secretive agency leads most intense anti-corruption effort in modern Chinese history. Washington Post. Available from: http://www.washingtonpost.com/world/asia_pacific/secretive-agency-leads-mostintense-anti-corruption-effort-in-modern-chinese-history/2014/07/02/48aff932-cf68-11e3-937fd3026234b51c_story.html

Watt, J (1974) The district magistrate in late imperial China. Bulletin of the School of Oriental and African Studies, Vol.37

Xiaochun, M (2014) Party to Address Rule of Law. People's Daily. Available from: http://en.people.cn/n/2014/1017/c90785-8796233.html

$\mathrm{Xu}, \mathrm{T}$ (2008) A correct concept of judicial authority is the proper meaning of rule of law. China Court Daily. Available from: http://old.chinacourt.org/html/article/200710/18/270093.shtml 